\title{
Genome-wide Identification and Analysis of the MADS-box Gene Family in Melon
}

\author{
Xin Hao, Yu Fu, Wei Zhao, Lifei Liu, Rengui Bade, Agula Hasi, and Jinfeng Hao ${ }^{1}$ \\ Inner Mongolia Key Laboratory of Herbage and Endemic Crop Biotechnology, College of Life \\ Sciences, Inner Mongolia University, Hohhot, Inner Mongolia, People's Republic of China
}

\begin{abstract}
AdDitional INDEX words. Cucumis melo, transcription factor, phylogenetic analysis, expression analysis, gene structure
ABstract. The MADS-box gene family encodes a type of transcription factor, and plays a key role in the growth and development of plants. Here, we identified 62 MADS-box genes in the melon (Cucumis melo) genome using

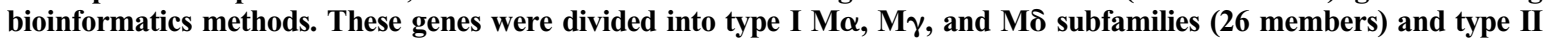
MIKC $^{\mathrm{C}}$ subfamilies (36 members) by phylogenetic analysis. There were no genes in type II AGL12, BS, TM8, and MIKC* subfamilies, and type I M $\beta$ subfamilies. Conserved motif analysis showed that all motifs had a subfamilyspecific distribution except the $M$ domain. The expression analysis of the MADS-box genes showed different expression characteristics. In summary, this study is the first to identify melon MADS-box genes and analyze their gene structures, subfamily distribution, and expression characteristics. These results provide a foundation for investigating the functions of the melon MADS-box genes.
\end{abstract}

The MADS-box gene family, which encodes a type of transcription factor, is a regulatory gene family found widely in eukaryotic genomes. Researchers successively found MADS-box genes in fungi (Passmore et al., 1988), animals (Norman et al., 1988), and plants (Sommer et al., 1990; Yanofsky et al., 1990). The MADS-box genes received their name from the first initials of four transcription factors, MCM1 (Mini Chromosome Maintenance 1) from Saccharomyces cerevisiae (Passmore et al., 1988), AG (AGAMOUS) from arabidopsis [Arabidopsis thaliana (Yanofsky et al., 1990)], DEF (Deficiens) from Antirrhinum majus (Sommer et al., 1990), and Serum Response Factor (SRF) from Homo sapiens (Norman et al., 1988). The proteins contain a conserved region of $\approx 58-60$ amino acids in their N-termini called the MADSbox (Becker et al., 2000; Theissen et al., 2000), which is a domain-binding DNA sequence that recognizes CArG boxes and regulates the expression of target genes (De Bodt et al., 2003). Studies have shown that plant MADS-box transcription factors play an important role in the control of floral organ and fruit development, flowering time, and gametophyte cell division (Ditta et al., 2004; Fang and Fernandez, 2002; Favaro et al., 2003; Liljegren et al., 2000; Ma, 2005; Michaels et al., 2003; Pinyopich et al., 2003).

Plant MADS-box genes can be divided into two categories, types I and II (Alvarez-Buylla et al., 2000). In comparison with type II, type I genes have a simpler gene structure and lack the $\mathrm{K}$ domain. In arabidopsis, type I MADS-box genes contain $\mathrm{M} \alpha$, $\mathrm{M} \beta, \mathrm{M} \gamma$, and $\mathrm{M} \delta$ subfamilies (Par̆enicová et al., 2003). Studies on type II genes have been relatively extensive, but type I genes have been less researched and are less well understood. Type II MADS-box genes can also be further subdivided into MIKC* and 13 MIKC $^{\mathrm{C}}$ subfamilies (Díaz-Riquelme et al., 2009; Henschel et al., 2002): AG, AGL6, AGL12, AGL15, AGL17, AP1/FUL, AP3/PI, FLC, SCO1, SEP, SVP, BS, and TM8. In

Received for publication 24 Feb. 2016. Accepted for publication 6 July 2016. This work was supported by the National Natural Science Foundation of China (no. 31101559) and the Inner Mongolia Natural Science Foundation of China (no. 2011MS0503).

${ }^{1}$ Corresponding author. E-mail: haojindd@163.com. addition to the M domain, MADS-box genes have three other conserved domains: the $\mathrm{K}$ domain, which is relatively conserved and characterized by a coiled-coil structure, only exists in type II genes and is the basis of the distinction between type I and II genes (Davies et al., 1996; Ma et al., 1991; Pnueli et al., 1991); the I domain, which is located between the M and $\mathrm{K}$ domains, may contribute to specificity in the formation of DNA-binding dimers (Riechmann et al., 1996); and the C domain, which has multiple functions, can activate transcription in some MADS-box genes of yeast cells (Kramer et al., 1998). Compared with MIKC ${ }^{C}$-type genes, MIKC*-type genes contain a longer I domain and a shorter $\mathrm{K}$ domain.

MADS-box genes play a significant role in plant development processes, especially in floral organ development (Causier et al., 2002). The ABC model of floral development was established via studies on model plants, such as arabidopsis and A. majus (Coen and Meyerowitz, 1991). Subsequently, many MADS-box genes and proteins were fully researched and explored, and the widely accepted ABCDE model was proposed (Honma and Goto, 2001). In this model, A-function genes determine sepal development, A- and B-function genes codetermine petal development, B- and C-function genes codetermine stamen development, C-function genes control carpel development, D-function genes determine ovule development, and E-function genes regulate the development of various organs (Kaufmann et al., 2005; Ma, 2000; Pelaz et al., 2000).

Melon, a diploid eudicot plant, is an annual herbaceous vine. Widely cultivated, melon is an important horticultural crop and one of the most popular fruit. Melon has considerable economic value, especially in the Mediterranean and central Asian countries. Through plant genome projects, genome-wide sequencing has been completed for many model plants, such as corn [Zea mays (Schnable et al., 2009)], sorghum [Sorghum bicolor (Paterson et al., 2009)], soybean [Glycine max (Schmutz et al., 2010)], and grape [Vitis vinifera (Jaillon et al., 2007)]. The genome sequence and gene annotations for melon have also been published (Garcia-Mas et al., 2012), which has established a foundation for studying the melon MADS-box gene family. There has been relatively extensive 
research on MADS-box genes in arabidopsis (Pařenicová et al., 2003), poplar [Populus trichocarpa (Leseberg et al., 2006)], rice [Oryza sativa (Arora et al., 2007)], grape (Díaz-Riquelme et al., 2009), soybean (Shu et al., 2013), and cucumber [Cucumis sativus (Hu et al., 2012)], but, so far, in-depth research on melon MADS-box genes has not been performed. Melon, as a model plant for fresh fruit, has important scientific value and significance warranting further discussion and research on the melon MADS-box gene family.

\section{Materials and Methods}

IDENTIFICATION OF MADS-Box GENES IN MELON. The melon genome was downloaded from the MELONOMICS database (Pere and Jordi, 2012). First, a protein database was established with the genome-wide amino acid sequence using the BioEdit 7.2.0 software (Hall, 1999), and then a Hidden Markov Model (HMM) for the SRF-TF (PF00319) and K-box (PF01486) was found from the Pfam database (Finn, 2014) and used as a probe to perform local protein alignment with the local Basic Local Alignment Search Tool (BLASTp) program. When conducting the alignment, the program was set to the default parameters and the cutoff E-value was 0.001. The alignment results were used to identify candidate genes, and then conserved domain analysis was conducted with the SMART program (Letunic et al., 2015; Schultz et al., 1998) to remove repetitive and redundant sequences. Finally, the complete set of melon MADS-box family genes was obtained.

INTRON-EXON STRUCTURE ANALYSIS AND CHROMOSOMAL LOCATIONS. In the melon database, the CDS and DNA sequences of 62 melon MADS-box genes were numbered using the FASTA format. The distribution of exons and introns in the melon MADS-box genes was analyzed using the online software GSDS (Hu et al., 2015). According to the positional information for the melon MADS-box genes, we used the MapDraw software (Liu and Meng, 2003) to map the distribution of the melon MADS-box genes on the chromosomes.

Sequence alignment and Phylogenetic analysis. The arabidopsis MADS-box genome was downloaded from the Arabidopsis Information Resource (TAIR) website (Rhee et al., 2003). The cucumber MADS-box genome was downloaded from the cucumber database (BGI, 2009), which was released by the Institute of Vegetables and Flowers, Chinese Academy of Agricultural Sciences (IVF-CAAS). Multiple sequence alignment was performed using CLC Sequence Version 7.6.1 (Qiagen, Duesseldorf, Germany) with default parameters. A phylogenetic tree was built with the MADS-box genes of arabidopsis, cucumber, and melon using the neighbor-joining method in the MEGA 4.1 software (Tamura et al., 2007), with the following parameters: Poisson correction, pairwise deletion, and bootstrapping (1000 replicates). All of the melon MADS-box genes were classified into subfamilies based on the phylogenetic tree.

Analysis of Conserved Motifs. MEME version 4.10.2 (Bailey and Elkan, 1994), a software tool for predicting conserved sequences of genes, was used to analyze the conserved motifs of the melon MADS-box genes (maximum number of motifs: 10 , motif width $>6$ and $<200$ ).

EXPRESSION ANALYSIS WITH REVERSE-TRANSCRIPTION POLYMERASE CHAIN REACTION AND QUANTITATIVE RT-PCR. Plants of melon cultivar Hetao were grown under experimental field conditions from May to July 2014 at Inner Mongolia University, Hohhot, China. At the flowering stage, we collected hermaphrodite flowers and fruit at $0 \mathrm{~d}$ after pollination (DAP), as well as young roots, leaf blades, and tender stems. Meanwhile, self-pollination was performed by hand and the pollination time was accurately controlled. Only one fruit was kept for each plant. The mesocarp of fruit (15 and 35 DAP) was collected. All harvested samples were immediately washed with sterile water, frozen in liquid nitrogen, and stored at $-80{ }^{\circ} \mathrm{C}$ for RNA extraction. TRIzol Reagent (Invitrogen, Carlsbad, CA) was used to extract RNA from all melon samples, and electrophoresis test results showed clear RNA bands and good integrity. Reverse transcription was performed with PrimeScript ${ }^{\mathrm{TM}}$ RT Master Mix (TaKaRa, Dalian, China) in a $10-\mu \mathrm{L}$ reaction system containing $2 \mu \mathrm{L} 5 \times$ buffer, $500 \mathrm{ng}$ RNA, and RNase-free $\mathrm{dH}_{2} \mathrm{O}$ up to $10 \mu \mathrm{L}$. The reaction conditions were $37^{\circ} \mathrm{C}$ for $15 \mathrm{~min}$ and $85^{\circ} \mathrm{C}$ for $5 \mathrm{~s}$. Aliquots of 4 and $2 \mu \mathrm{L}$ were taken as templates for reverse-transcription polymerase chain reaction (RT-PCR) and quantitative TR-PCR (qRT-PCR), respectively, after the reverse transcription product was diluted 10 times. We designed primers for the experiment with the Primer 5.0 software (Premier Biosoft, Palo Alto, CA); during the design process, we tried to avoid the conserved regions of MADS-box genes and design primers across long introns as far as possible to remove potential DNA contamination. After primer design was completed, the primers were aligned to the melon database to confirm their specificity. All PCR products were run on $2 \%$ agarose gels. For qRT-PCR, a $25-\mu \mathrm{L}$ reaction system was used containing $12.5 \mu \mathrm{L} 2 \times$ SYBR Premix Ex Taq II (TaKaRa), forward and reverse primers diluted to $0.4 \mu \mathrm{M}$, and the templates mentioned above. The reaction conditions were $95{ }^{\circ} \mathrm{C}$ for $30 \mathrm{~s}$, followed by 40 cycles of $95{ }^{\circ} \mathrm{C}$ for $5 \mathrm{~s}$ and $60{ }^{\circ} \mathrm{C}$ for $30 \mathrm{~s}$. The reactions were performed with a Chromo 4 Real-Time PCR Detector (Bio-Rad, Hercules, CA). The relative expression of genes was calculated by the $2^{(-\Delta \Delta \mathrm{Ct})}$ method. At least three technical replicates were performed for each reaction and three biological samples were used for each gene.

\section{Results}

IDENTIFICATION, GENOMIC DISTRIBUTION, AND ANNOTATION OF MADS-Box GENES IN MELON. To identify melon MADS-box family genes, we used the HMM model for the SRF-TF (PF00319) and K-box (PF01486) to conduct local protein alignment and collected the results as candidate proteins. After we removed duplicated and functionally redundant genes, 62 MADS-box genes remained. Analysis with the SMART software shows that all 62 genes had a typical MADS-box domain. We named the genes CmMADS01-CmMADS62 according to their distribution of subfamily and collected relative statistics about them (Table 1). Table 1 shows the corresponding statistics and analysis, including amino acid length, number of exons and introns, chromosomal assignment, and subfamily classification.

We mapped the chromosomal locations of the genes based on their location information using the MapDraw software (Fig. 1). This showed that the gene family was differentially distributed across the chromosomes. Chr8 and Chr11 both had eight genes, whereas Chr5 had no genes. The remaining chromosomes contained one to seven genes. Chrl had two type II genes but no type I genes, whereas Chr2 and Chr10 only had one type I gene each but no type II genes. The gene distribution on the other chromosomes was about equal. 
Table 1. Identity of 62 MADS-box genes from a local blast against melon genome and removed repetitive and redundant sequences with the SMART program (Letunic et al., 2015). Obtained the information including amino acid length, number of exons and introns, and chromosomal assignment. The subfamilies were classified based on the phylogenetic tree.

\begin{tabular}{|c|c|c|c|c|c|c|c|}
\hline Gene & Gene identification & Location & Chromosome no. & $\begin{array}{c}\text { Protein } \\
\text { length (no. } \\
\text { of amino acids) }\end{array}$ & $\begin{array}{c}\text { Exons } \\
\text { (no.) }\end{array}$ & $\begin{array}{c}\text { Introns } \\
\text { (no.) }\end{array}$ & Subfamily \\
\hline CmMADS01 & MELO3C002691T1 & Scaffold00001 5563523-5568056 & 12 & 256 & 8 & 7 & $\mathrm{AG}$ \\
\hline CmMADS02 & MELO3C007181T1 & Scaffold00007 1322082-1329014 & 8 & 237 & 9 & 8 & $\mathrm{AG}$ \\
\hline CmMADS03 & MELO3C007181T2 & Scaffold00007 1322082-1329014 & 8 & 242 & 9 & 8 & $\mathrm{AG}$ \\
\hline CmMADS04 & MELO3C007181T3 & Scaffold00007 1322082-1329266 & 8 & 262 & 9 & 8 & $\mathrm{AG}$ \\
\hline CmMADS05 & MELO3C022209T1 & Scaffold00051 2262147-2270592 & 9 & 230 & 9 & 8 & $\mathrm{AG}$ \\
\hline CmMADS06 & MELO3C022516T1 & Scaffold00052 2287507-2292344 & 11 & 187 & 7 & 6 & AGL6 \\
\hline CmMADS07 & MELO3C022516T2 & Scaffold00052 2287507-2292344 & 11 & 249 & 8 & 7 & AGL6 \\
\hline CmMADS08 & MELO3C024001T1 & Scaffold00064 990832-994894 & 4 & 251 & 8 & 7 & AGL15 \\
\hline CmMADS09 & MELO3C019192T1 & Scaffold00036 4133578-4136082 & $\mathrm{N} / \mathrm{A}^{\mathrm{z}}$ & 135 & 4 & 3 & AGL15 \\
\hline CmMADS10 & MELO3C003502T1 & Scaffold01596 1775790-1799198 & 4 & 238 & 9 & 8 & AGL17 \\
\hline CmMADS11 & MELO3C003502T2 & Scaffold01596 1775876-1799198 & 4 & 239 & 9 & 8 & AGL17 \\
\hline CmMADS12 & MELO3C007700T1 & Scaffold00007 4765228-4767238 & 8 & 150 & 4 & 3 & AGL17 \\
\hline CmMADS13 & MELO3C018049T1 & Scaffold00031 3970196-3980905 & 7 & 190 & 6 & 5 & AGL17 \\
\hline CmMADS14 & MELO3C002050T1 & Scaffold00001 900368-905507 & 12 & 248 & 8 & 7 & AP1/FUL \\
\hline CmMADS15 & MELO3C011409T1 & Scaffold00014 5441565-5446683 & 3 & 151 & 3 & 2 & AP1/FUL \\
\hline CmMADS16 & MELO3C003778T1 & Scaffold01596 4117765-4122123 & 4 & 270 & 7 & 6 & AP3/PI \\
\hline CmMADS17 & MELO3C010515T1 & Scaffold00013 3450090-3454750 & 7 & 248 & 7 & 6 & AP3/PI \\
\hline CmMADS18 & MELO3C022315T1 & Scaffold00052 754375-771989 & 11 & 189 & 5 & 4 & FLC \\
\hline CmMADS19 & MELO3C005617T1 & Scaffold00005 6499878-6505422 & 9 & 151 & 6 & 5 & $\mathrm{SCO} 1$ \\
\hline CmMADS20 & MELO3C005617T2 & Scaffold00005 6499878-6505422 & 9 & 223 & 7 & 6 & SCO1 \\
\hline CmMADS21 & MELO3C005393T1 & Scaffold00005 4706570-4715038 & 9 & 160 & 7 & 6 & SCO1 \\
\hline CmMADS22 & MELO3C006159T2 & Scaffold00006 1394377-1397731 & 6 & 160 & 4 & 3 & $\mathrm{SCO} 1$ \\
\hline CmMADS23 & MELO3C006159T4 & Scaffold00006 1394377-1400874 & 6 & 221 & 7 & 6 & $\mathrm{SCO} 1$ \\
\hline CmMADS24 & MELO3C002049T1 & Scaffold00001 891449-895415 & 12 & 258 & 8 & 7 & SEP \\
\hline CmMADS25 & MELO3C022316T1 & Scaffold00052 778977-784983 & 11 & 242 & 8 & 7 & SEP \\
\hline CmMADS26 & MELO3C026300T1 & Scaffold00090 352986-362937 & N/A & 246 & 8 & 7 & SEP \\
\hline CmMADS27 & MELO3C026300T2 & Scaffold00090 352986-362937 & N/A & 216 & 7 & 6 & SEP \\
\hline CmMADS28 & MELO3C026300T3 & Scaffold00090 354020-362937 & N/A & 181 & 6 & 5 & SEP \\
\hline CmMADS29 & MELO3C007716T1 & Scaffold00007 4865399-4870497 & 8 & 228 & 9 & 8 & SVP \\
\hline CmMADS30 & MELO3C011093T1 & Scaffold00014 2864281-2871142 & 3 & 230 & 8 & 7 & SVP \\
\hline CmMADS31 & MELO3C011093T2 & Scaffold00014 2864281-2871263 & 3 & 216 & 8 & 7 & SVP \\
\hline CmMADS32 & MELO3C011093T3 & Scaffold00014 2864281-2871263 & 3 & 258 & 9 & 8 & SVP \\
\hline CmMADS33 & MELO3C011093T4 & Scaffold00014 2865897-2871263 & 3 & 167 & 8 & 7 & SVP \\
\hline CmMADS34 & MELO3C018055T1 & Scaffold00031 4022390-4027175 & 7 & 218 & 5 & 4 & SVP \\
\hline CmMADS35 & MELO3C018601T1 & Scaffold00034 1382310-1411114 & 1 & 222 & 9 & 8 & SVP \\
\hline CmMADS36 & MELO3C018601T2 & Scaffold00034 1384447-1411114 & 1 & 218 & 8 & 7 & SVP \\
\hline CmMADS37 & MELO3C002723T1 & Scaffold00001 5929497-5930018 & 12 & 173 & 1 & 0 & $\mathrm{M} \alpha$ \\
\hline CmMADS38 & MELO3C003801T1 & Scaffold01596 4730952-4731518 & 4 & 188 & 1 & 0 & $\mathrm{M} \alpha$ \\
\hline CmMADS39 & MELO3C007148T1 & Scaffold00007 1127180-1128076 & 8 & 298 & 1 & 0 & $\mathrm{M} \alpha$ \\
\hline CmMADS40 & MELO3C018030T1 & Scaffold00031 3839201-3840317 & 7 & 226 & 2 & 1 & $\mathrm{M} \alpha$ \\
\hline CmMADS41 & MELO3C020871T1 & Scaffold00045 1926450-1927007 & 11 & 185 & 1 & 0 & $\mathrm{M} \alpha$ \\
\hline CmMADS42 & MELO3C021689T1 & Scaffold00049 435118-435798 & 12 & 212 & 1 & 0 & $\mathrm{M} \alpha$ \\
\hline CmMADS43 & MELO3C023227T1 & Scaffold00059 371350-372536 & 11 & 365 & 2 & 1 & $\mathrm{M} \gamma$ \\
\hline CmMADS44 & MELO3C009552T1 & Scaffold000113058228-3059613 & 4 & 386 & 1 & 0 & $\mathrm{M} \gamma$ \\
\hline CmMADS45 & MELO3C015239T1 & Scaffold00025 184813-185792 & 2 & 223 & 2 & 1 & $\mathrm{M} \gamma$ \\
\hline CmMADS46 & MELO3C021692T1 & Scaffold00049 456773-457432 & 12 & 219 & 1 & 0 & $\mathrm{M} \gamma$ \\
\hline CmMADS47 & MELO3C000260T1 & Contig32319 523-1093 & $\mathrm{N} / \mathrm{A}$ & 61 & 2 & 1 & $\mathrm{M} \delta$ \\
\hline CmMADS48 & MELO3C001111T1 & Contig38521 $110-449$ & N/A & 86 & 2 & 1 & $\mathrm{M} \delta$ \\
\hline CmMADS49 & MELO3C001991T1 & Scaffold00001 531621-534860 & 12 & 364 & 10 & 9 & $\mathrm{M} \delta$ \\
\hline CmMADS50 & MELO3C006159T1 & Scaffold00006 1394377-1396616 & 6 & 109 & 2 & 1 & M $\delta$ \\
\hline CmMADS51 & MELO3C006159T3 & Scaffold00006 1394377-1400874 & 6 & 120 & 6 & 5 & $\mathrm{M} \delta$ \\
\hline CmMADS52 & MELO3C006860T1 & Scaffold00006 6768245-6770216 & 6 & 97 & 2 & 1 & $\mathrm{M} \delta$ \\
\hline CmMADS53 & MELO3C007017T1 & Scaffold00007 215217-215411 & 8 & 64 & 1 & 0 & $\mathrm{M} \delta$ \\
\hline CmMADS54 & MELO3C008942T1 & Scaffold00010 3726274-3726758 & 8 & 102 & 2 & 1 & $\mathrm{M} \delta$ \\
\hline
\end{tabular}




\begin{tabular}{|c|c|c|c|c|c|c|c|}
\hline Gene & Gene identification & Location & Chromosome no. & $\begin{array}{c}\text { Protein } \\
\text { length (no. } \\
\text { of amino acids) }\end{array}$ & $\begin{array}{c}\text { Exons } \\
\text { (no.) }\end{array}$ & $\begin{array}{c}\text { Introns } \\
\text { (no.) }\end{array}$ & Subfamily \\
\hline CmMADS55 & MELO3C011410T1 & Scaffold00014 5456438-5456656 & 3 & 72 & 1 & 0 & $\mathrm{M} \delta$ \\
\hline CmMADS57 & MELO3C022205T1 & Scaffold00051 2234321-2236745 & 9 & 112 & 3 & 2 & $\mathrm{M} \delta$ \\
\hline CmMADS58 & MELO3C022315T3 & Scaffold00052 771547-771881 & 11 & 68 & 2 & 1 & $\mathrm{M} \delta$ \\
\hline CmMADS61 & MELO3C005617T3 & Scaffold00005 6501777-6505422 & 9 & 145 & 3 & 2 & $\mathrm{M} \delta$ \\
\hline CmMADS62 & MELO3C005617T4 & Scaffold00005 6504671-6505422 & 9 & 74 & 2 & 1 & $\mathrm{M} \delta$ \\
\hline
\end{tabular}

${ }^{\mathrm{z}}$ Chromosomal locations of these genes are not available.

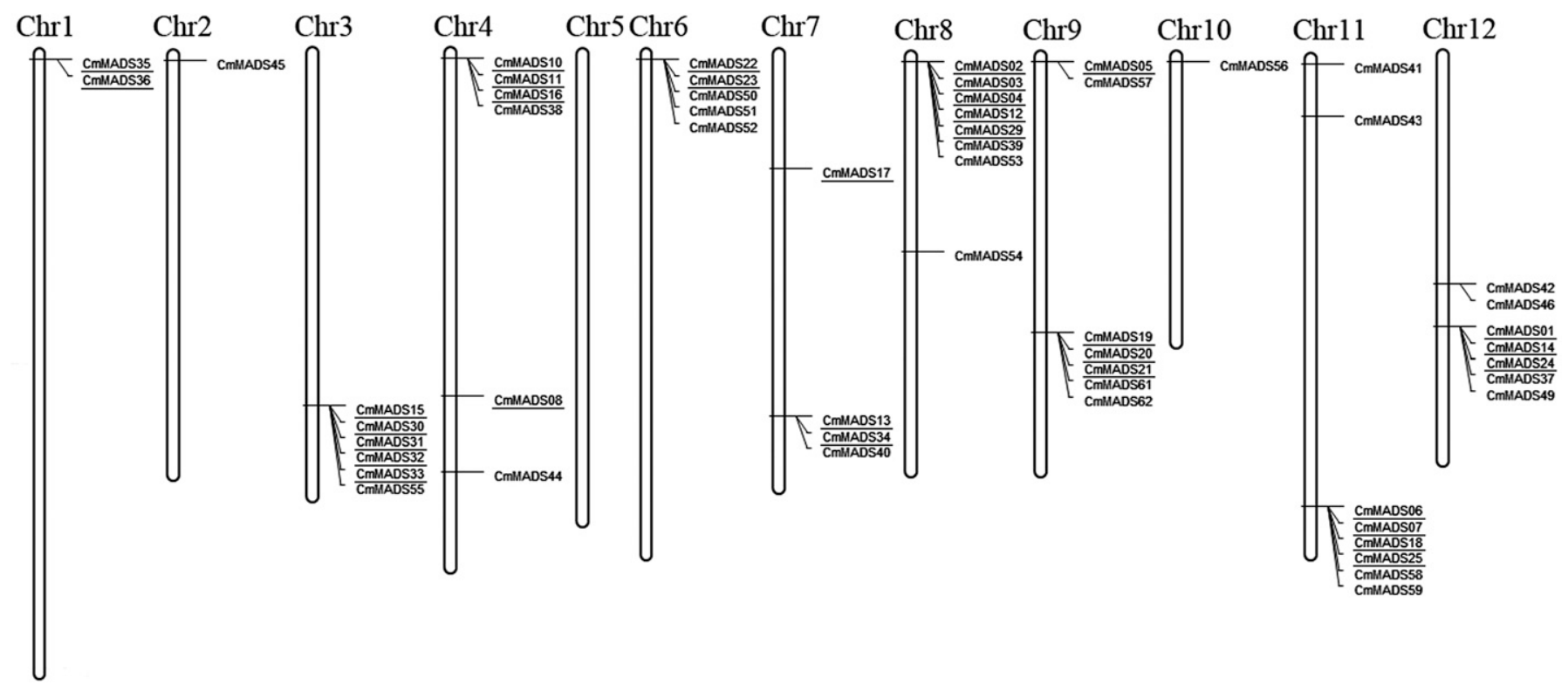

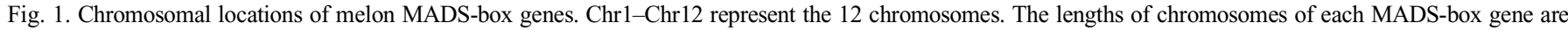
displayed proportionately. Black lines on bars indicate the locations of MADS-box genes. Type I genes were not underlined and type II genes were underlined.

Furthermore, CmMADS47 and CmMADS48 were located on Contig32319 and Contig38521 on Scaffold00090, the chromosomal location of which remains unknown. The genomic distribution result indicated that $61 \%$ of melon MADS-box genes were clustered, and most of them presented in groups of two or more genes separated by 10 to $600 \mathrm{~kb}$. It has been reported that a similar situation exists in arabidopsis, cucumber, and peach (Prunus persica) MADS-box genes. But the distribution of subfamily had no specificity.

We created a schematic of exon and intron structures (Fig. 2) based on the DNA and coding sequences of the genes, which showed that most type II genes had complex exon and intron structures and that there were 14 to $21 \mathrm{~kb}$ long introns in CmMADS10, CmMADS11, CmMADS18, CmMADS35, and $C m M A D S 36$. Type I genes had simpler structures, with only one exon and no intron for CmMADS37,CmMADS38, CmMADS39, CmMADS41, CmMADS42, CmMADS44, CmMADS46, CmMADS53, CmMADS55, and CmMADS60. A relatively complex exon-intron structure was only observed in CmMADS49, CmMADS51, and CmMADS56 among type I genes; the others only had a few introns.
Phylogenetic analysis of melon MADS-box genes. To study the family relationships among the melon MADS-box genes and classify them into subfamilies, a phylogenetic tree was built after multiple sequence alignment of 62 CmMADSbox genes, 58 AtMADS-box genes, and 26 CsMADS-box genes using MEGA 5.1. The results corresponded with previous results for MADS-box genes. The 62 MADS-box genes of melon were divided into types I and II. There were 26 genes (CmMADS37-CmMADS62) in type I, which was further subdivided into the M $\alpha$ (6 members), M $\gamma$ (4 members), M $\delta$ (16 members), and $\mathrm{M} \beta$ (0 members) subfamilies (Fig. 3). Type II included 36 genes, which belonged to the MIKC ${ }^{\mathrm{C}}$ subfamily and were distributed in 10 subclasses: SEP (5 members), AGL6 (2), AP1/FUL (2), SCO1 (5), AG (5), AGL17 (4), AGL15 (2), AP3/PI (2), SVP (8), and FLC (1); there were no genes in the AGL12, BS, TM8, and MIKC* groups (Fig. 4). Meanwhile, we collected and organized the number of MADS-box subfamily of arabidopsis, rice, peach, Chinese cabbage (Brassica rapa), soybean, and cucumber (Table 2), and compared them with melon. According to the statistics, the melon MADS-box gene family has roughly the same 


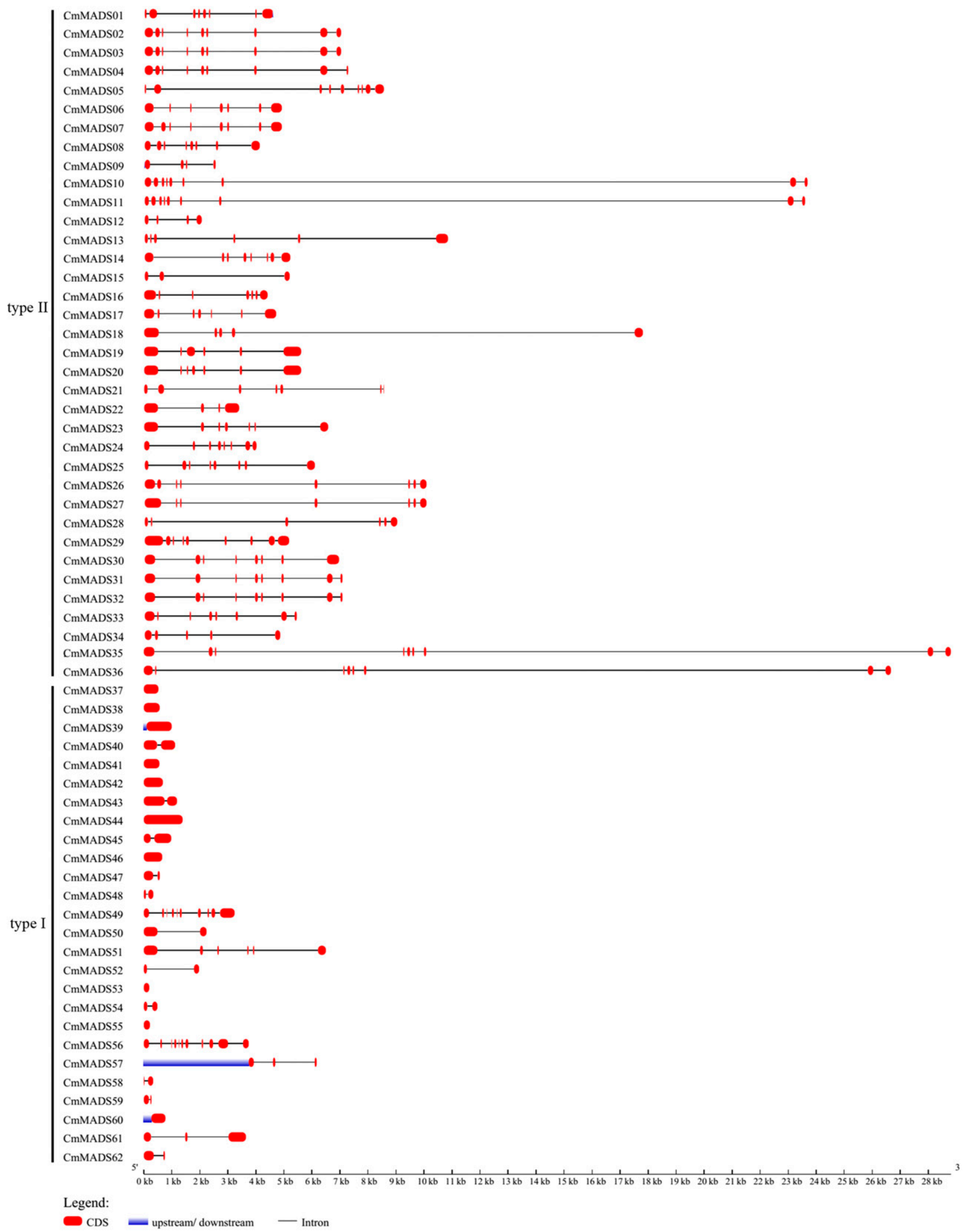

Fig. 2. Exon-intron structures of the melon MADS-box genes. Introns and exons are represented by black lines and red solid boxes, respectively. Blue bold lines represent upstream/downstream regions; $\mathrm{CDS}=$ coding sequence.

characteristics as in the abovementioned species, but also shows obvious specificity. There are no genes distributing on $\mathrm{M} \beta$ and MIKC* subfamily in melon, whereas the gene number of $\mathrm{M} \delta$ subfamily is more than other pieces.
Conserved Motif ANALYSIS. To examine the characteristics of the melon MADS-box gene family and the conserved motifs of different subfamilies, we searched for motifs via the MEME software and found 10, which we named motifs 1-10 (Fig. 5). 


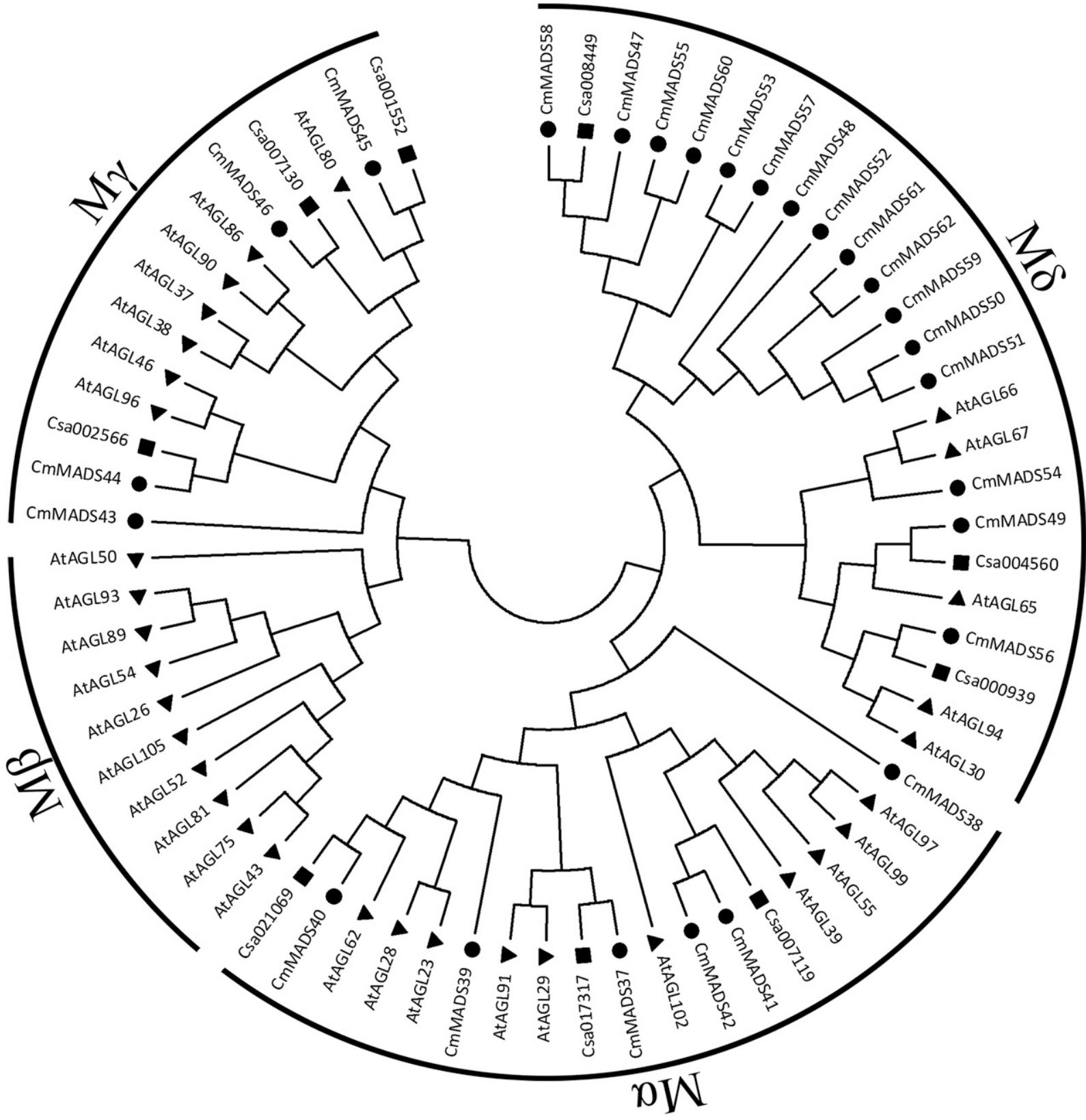

Fig. 3. Phylogenetic relationships of 26 type I melon MADS-box genes to their homologs in arabidopsis and cucumber. The tree was constructed using the MEGA software [version 4.1 (Tamura et al., 2007)]. The bootstrap value is 1000. Triangles indicate arabidopsis MADS-box genes, squares indicate cucumber, and dots indicate melon.

All 62 melon MADS-box proteins had motif 1, which was found in the N-terminus and is an essential conserved motif for the MADS-box gene family as it encodes the MADS-box domain. Motif 2 was recognized as the highly conserved $\mathrm{K}$ domain, which is found in all type II genes and is an important criterion to distinguish type I and II genes. Although the $\mathrm{K}$ domain was found in the CmMADS09 and CmMADS18 genes by SMART, it was not observed in these genes in the motif distribution diagram. Motif 4 was only found in MIKC-type genes, not in type I MADS-box genes. Motifs 7 and 8 were only found in the SVP subfamily. Motifs 6, 9, and 10 were present in the AG, M $\gamma$, and AGL17 subfamilies, respectively. Motifs 3 and 5 were found in both type I and II genes. The degree of motif conservation was relatively low except for motifs 1 and 2 .
EXPRESSION ANALYSIS IN DIFFERENT TISSUES. To explore the expression patterns of the melon MADS-box genes in different tissues, we conducted RT-PCR analysis on the 62 MADS-box genes in roots, stems, leaves, flowers, and fruit (0 DAP), and qRTPCR using 20 genes with tissue-specific expression (underlined in Figs. 6 and 7) in roots, stems, leaves, flowers, and fruit $(0,15$, and 35 DAP). The qRT-PCR assays of expression levels in fruit at 15 and 35 DAP were performed because 15 DAP represents the melon development period and $35 \mathrm{DAP}$ represents the mature period. Because CmMADS06 shared high sequence similarity with CmMADS07, CmMADS10 with CmMADS11, CmMADS19 with CmMADS20, CmMADS26 with CmMADS27, and CmMADS50 with CmMADS51, the use of gene-specific primer pairs (Supplement 1) was impossible. Therefore, the transcript levels measured for these genes 


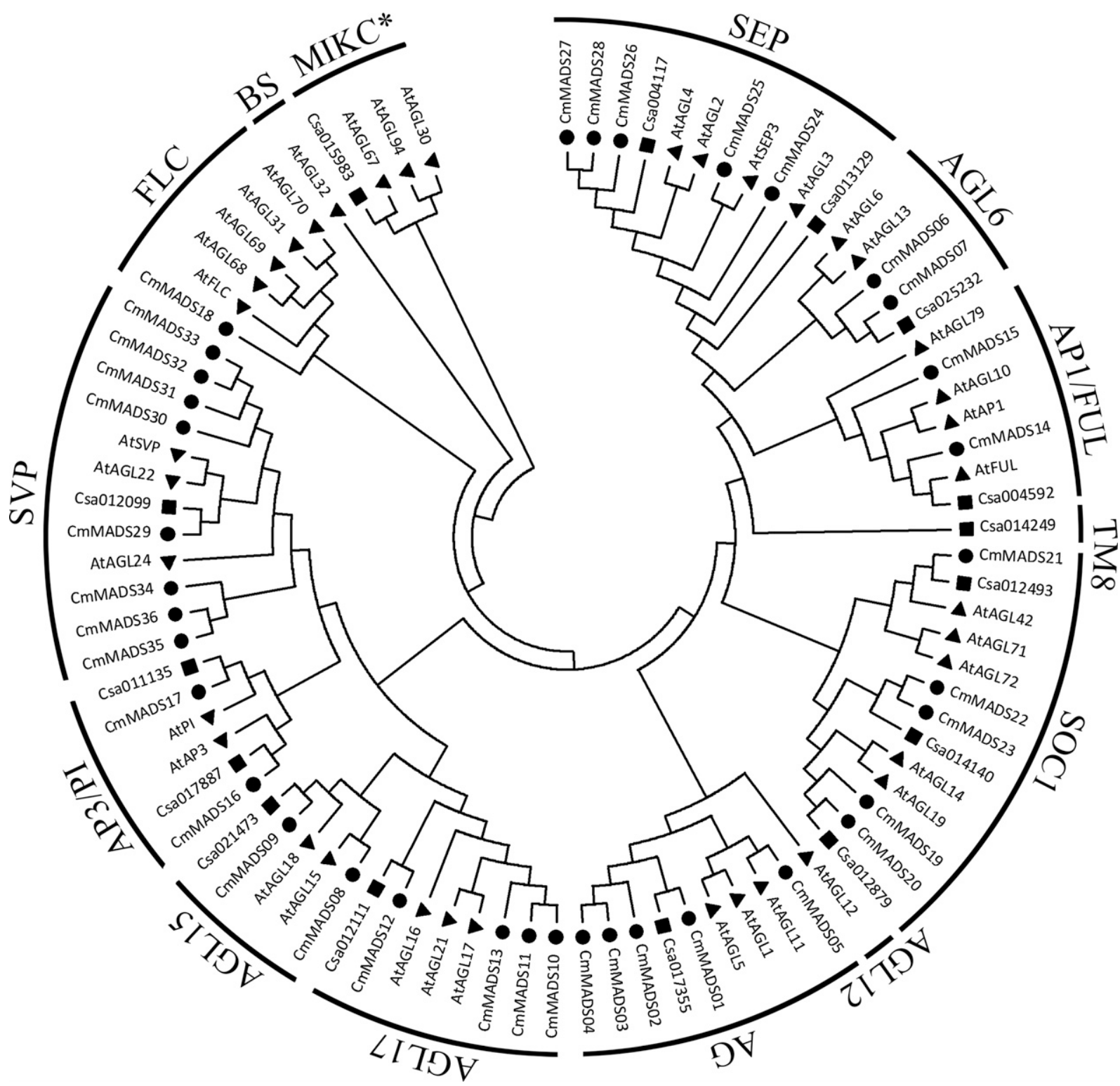

Fig. 4. Phylogenetic relationships of 36 type II melon MADS-box genes to their homologs in arabidopsis and cucumber. The tree was constructed using the MEGA software [version 4.1 (Tamura et al., 2007)]. The bootstrap value is 1000. Triangles indicate arabidopsis MADS-box genes, squares indicate cucumber, and dots indicate melon.

Table 2. Numbers of MADS-box subfamily in seven species. The MADS-box genes were divided members varied in different organs. into type I and II genes. Type I genes contained $\mathrm{M} \alpha, \mathrm{M} \beta, \mathrm{M} \gamma$, and $\mathrm{M} \delta$ subfamilies. Type II genes The RT-PCR and qRT-PCR analyses contained MIKC ${ }^{\mathrm{C}}$ and MIKC* subfamilies (Henschel et al., 2002; Pařenicová et al., 2003).

\begin{tabular}{|c|c|c|c|c|c|c|c|}
\hline \multirow[b]{3}{*}{ Species } & \multicolumn{6}{|c|}{ Subfamilies (no.) } & \multirow[b]{3}{*}{ Total (no.) } \\
\hline & \multicolumn{4}{|c|}{ Type I } & \multicolumn{2}{|c|}{ Type II } & \\
\hline & $\overline{\mathrm{M} \alpha}$ & $\mathrm{M} \beta$ & $\mathrm{M} \gamma$ & $\mathrm{M} \delta$ & $\mathrm{MIKC}^{\mathrm{C}}$ & MIKC* & \\
\hline Arabidopsis thaliana (Par̆enicová et al., 2003) & 20 & 17 & 21 & 4 & 43 & 2 & 107 \\
\hline Oryza sativa (Arora et al., 2007) & 13 & 9 & 10 & 0 & 38 & 5 & 75 \\
\hline Prunus persica (Wells et al., 2015) & 21 & 7 & 12 & 0 & 35 & 4 & 79 \\
\hline Brassica rapa (Duan et al., 2014) & 27 & 16 & 22 & 0 & 84 & 11 & 160 \\
\hline Glycine $\max$ (Shu et al., 2013) & 18 & 5 & 11 & 0 & 67 & 5 & 106 \\
\hline Cucumis sativus (Hu et al., 2012) & 5 & 2 & 3 & 3 & 29 & 1 & 43 \\
\hline Cucumis melo & 6 & 0 & 4 & 16 & 36 & 0 & 62 \\
\hline
\end{tabular}
showed that the expression levels of AG subclass genes, which were specifically expressed in fruit, gradually declined during fruit development and ripening, although the expression level of CmMADSO4 was too low to show this. Only one gene (CmMADSO6) of the AGL6 subfamily was specifically expressed in flowers and fruit (0 DAP) (Fig. 6). This gene had extremely low or no expression in different developmental stages of other tissues or fruit. In the AP1/FUL subfamily, CmMADS14

were only indicative of the mixed transcript level. The gene expression patterns within each group were often conserved to some extent, although the expression levels of specific and $C m M A D S 15$ were specifically expressed in flowers and fruit (Fig. 6), and the transcript level of CmMADS14 during the fruit development stage was relatively high (Fig. 8). 


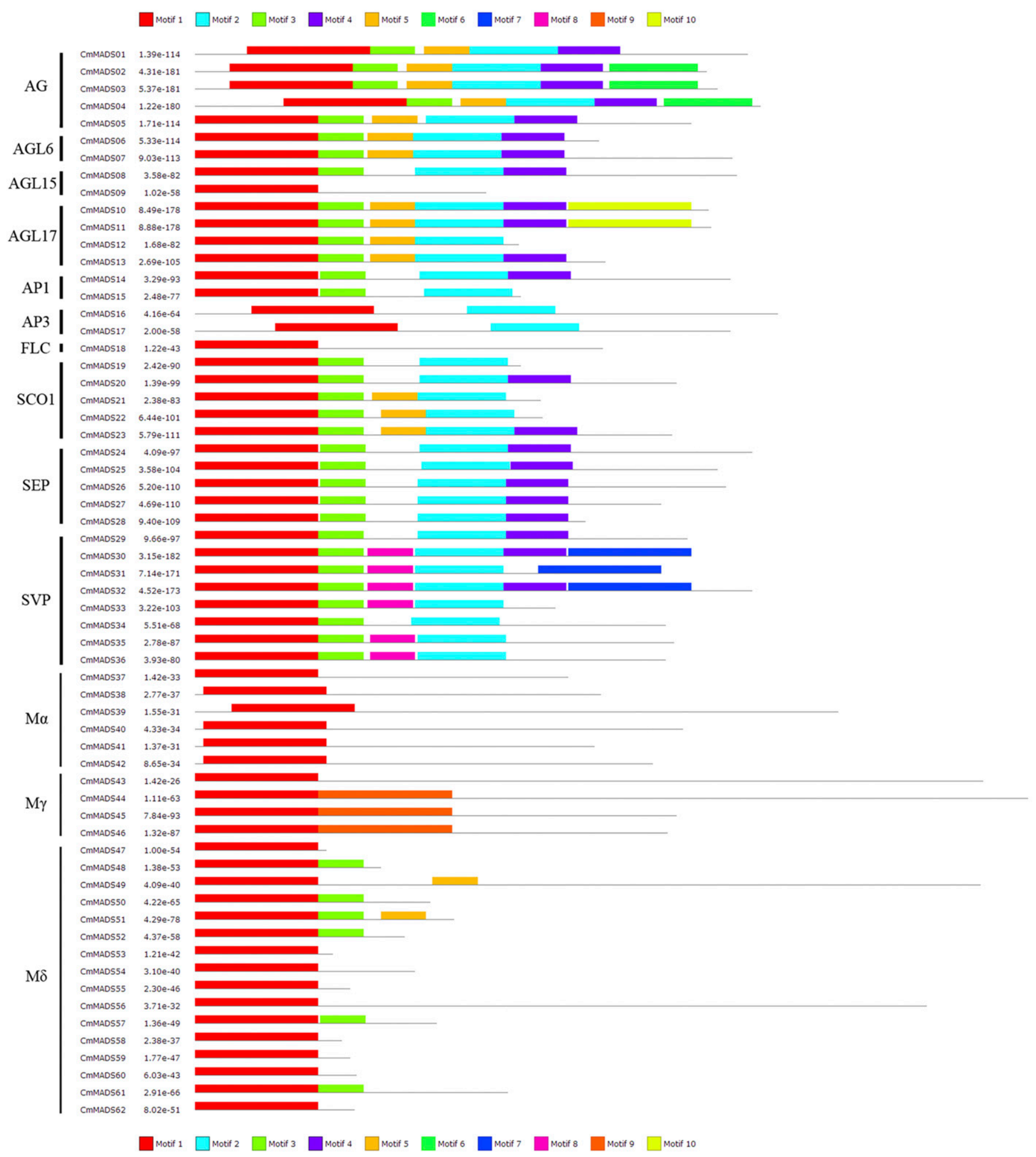

Fig. 5. Conserved motifs of melon MADS-box proteins identified using the MEME program. Motifs 1 to 10 are indicated by different colored boxes. The names of all members and combined probability values are shown on the left side; motif sizes are shown at the bottom. The order of the motifs corresponds to their positions in individual protein sequences.

Although CmMADS16 had low expression in leaves and fruit, the AP3/PI subfamily showed specific expression in flowers. CmMADS17 showed an extremely high expression level in flowers (Fig. 8). Most SEP subfamily genes were specifically expressed in flowers and fruit. During fruit development,
CmMADS25 showed rapid downregulation of expression and CmMADS26 was upregulated and maintained a high transcript level, even entering into the mature period. The expression of AGL17 subclass genes was specific to and high in roots. The expression levels of SVP subclass genes were different in 


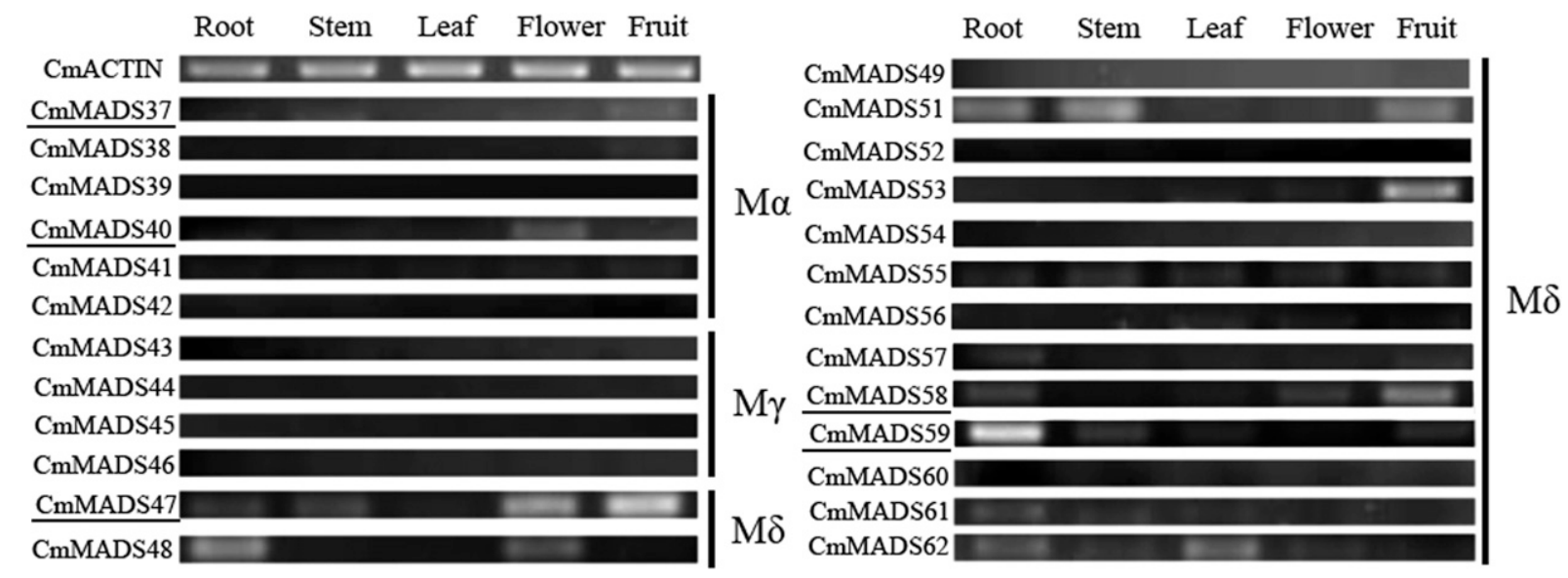

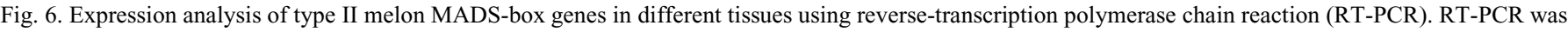
performed using primers specific to each gene. PCR products were run on $2 \%$ agarose gels. CmACTIN was used as an internal standard for each gene. The roots, stems, leaf, flowers, and fruit at $0 \mathrm{~d}$ after pollination were collected from melon plant at the flowering stage. The expressions of the underlined genes were analyzed by quantitative real-time RT-PCR.

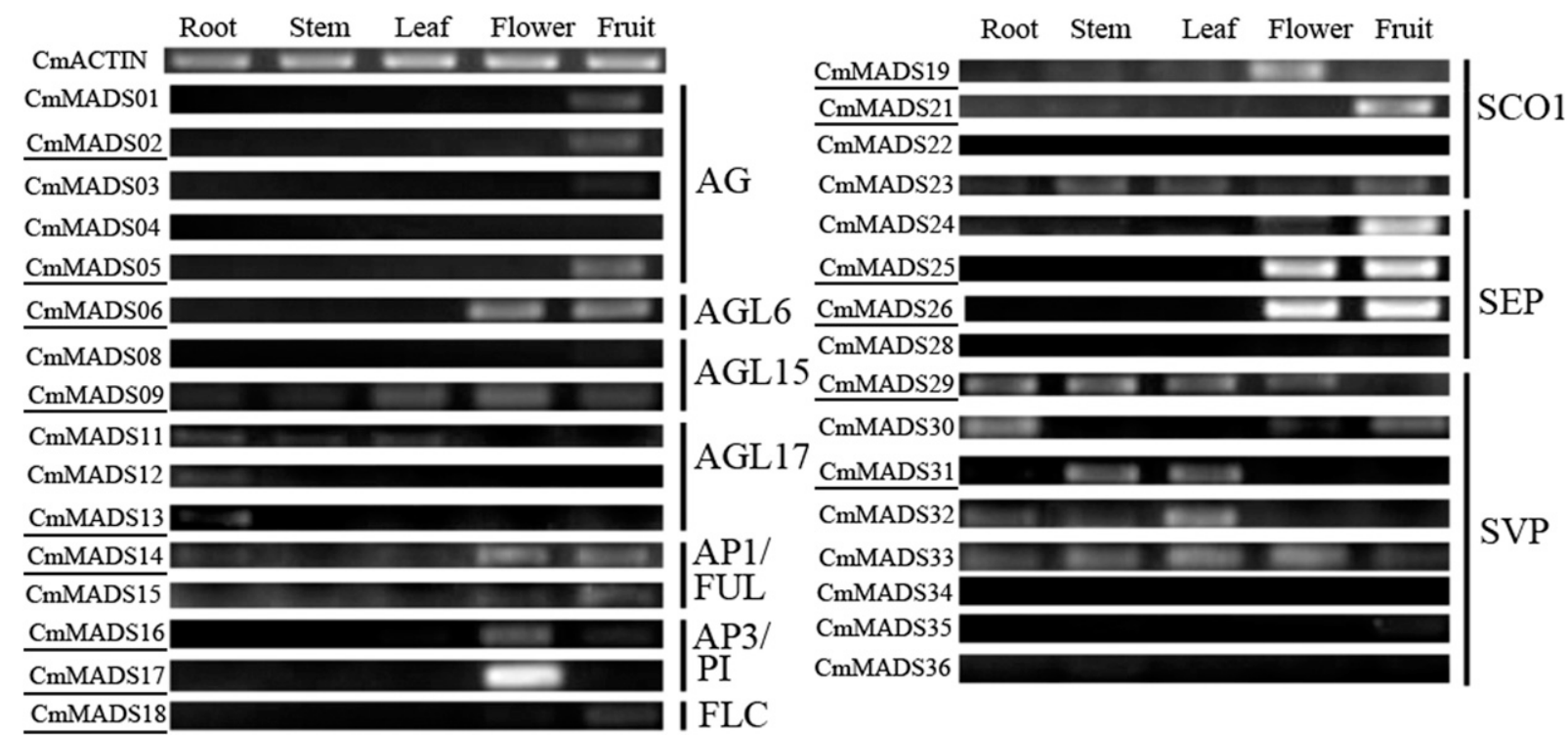

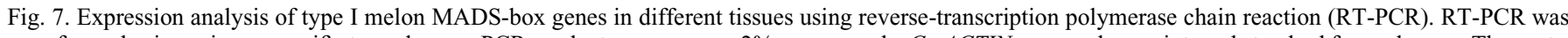
performed using primers specific to each gene. PCR products were run on $2 \%$ agarose gels. CmACTIN was used as an internal standard for each gene. The roots, stems, leaf, flowers, and fruit at $0 \mathrm{~d}$ after pollination were collected from melon plant at the flowering stage. The expressions of the underlined genes were analyzed by quantitative real-time RT-PCR.

different tissues, being highest in leaves and hardly detectable in fruit (Figs. 6 and 8). Among type I genes, the expression of $\mathrm{M} \alpha$ and $\mathrm{M} \gamma$ subfamily members was low (Fig. 7), but relative quantitative results showed that M $\alpha$ MADS37 and MADS40 had relative high expression in fruit of 35 DAP and flowers (Fig. 8). The M $\delta$ subfamily genes showed diverse expression in different tissues, such as a high expression levels for CmMADS47, CmMADS58, and CmMADS59 in fruit (35 DAP), fruit (0 DAP), and roots, respectively (Fig. 8). CmMADS47 was specifically expressed in flower and the different stage of fruit (Fig. 7), and the expression level was highest at the mature fruit (Fig. 8).

\section{Discussion}

In recent years, with the rise and development of sequencing techniques, bioinformatics has rapidly expanded.
Bioinformatics-based prediction and detailed studies of the MADS-box gene family have been performed in many species. In this study, we identified and analyzed the MADS-box gene family in melon, finding 62 MADS-box genes. There are more $\mathrm{MIKC}^{\mathrm{C}}$-type genes than MIKC*-type genes in some plant species, such as arabidopsis, cucumber, and apple, whereas MIKC*-type genes are not found in melon. Previous research has shown that MIKC*-type MADS-box genes have a large influence on pollen viability. MIKC*-type gene mutations lead to extremely reduced pollen fecundity, because of reduced pollen viability, delayed germination, and aberrant pollen tube growth (Adamczyk and Fernandez, 2009). So other genes in melon could regulate the pollen viability and fecundity. Type I MADS-box genes are divided into the $\mathrm{M} \alpha, \mathrm{M} \beta, \mathrm{M} \gamma$, and $\mathrm{M} \delta$ subfamilies, and have a diverse distribution in the representative species mentioned above. 

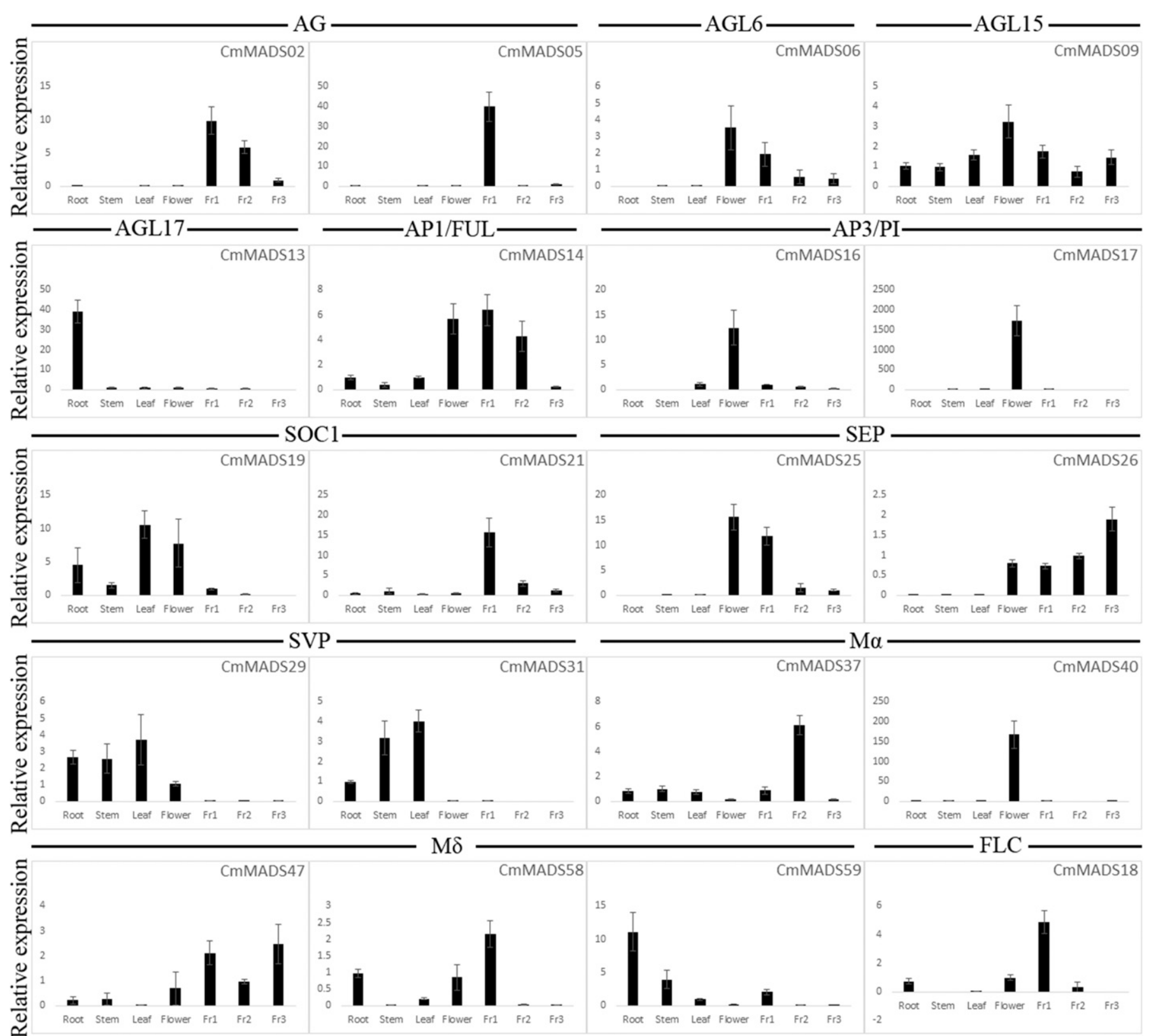

Fig. 8. Expression analysis of selected melon MADS-box genes in different tissues and three fruit development stages using quantitative reverse-transcription polymerase chain reaction. CmACTIN was used as an internal standard for each gene. The mean expression value was calculated from nine independent replicates. The vertical bars indicate the standard deviation. Fruit at $0 \mathrm{~d}$ after pollination [DAP (Fr1)], fruit at $15 \mathrm{DAP}(\mathrm{Fr} 2)$, and fruit at $35 \mathrm{DAP}$ (Fr3).

Generally, few or no genes are distributed in $\mathrm{M} \delta$. We found no $\mathrm{M} \beta$ subfamily genes in melon, which means that $\mathrm{M} \beta$ subfamily genes are not essential for melon or that their functions have been replaced by other genes. Furthermore, we found 16 members in the M $\delta$ subfamily, whose ratio (61.5\%) in type I was higher than in the above mentioned species. We know little about the functions of type I MADS-box genes, so the significance of the distribution of these two subfamilies remains unclear. In arabidopsis, the AGL12 gene is closely related with the development of roots (Tapia-López et al., 2008), and overexpression of this gene in rice not only influences root development, but also induces chlorosis, cell death, and pigment accumulation (Lee et al., 2008). However, we did not find any AGL12 subclass genes in melon, suggesting root development and pigment accumulation are not regulated by AGL12 subclass genes in melon. The TT16 gene in arabidopsis, belonging to the BS group, has a confirmed correlation with seed coloring (Nesi et al., 2002). No BS subfamily genes were found in melon, which may be related to the tendency of melon seeds to be colorless. Similarly, the AGL12 and BS subgroups are not found in cucumber (Hu et al., 2012), which has a close genetic relationship with melon, highlighting the affinity between these two species.

Our exon-intron structure analysis showed that melon type I MADS-box genes were relatively short and had simple structures, but MIKC-type genes had a complex structure with short or long introns. The $\mathrm{M} \alpha$ and $\mathrm{M} \gamma$ genes usually had no intron or a single intron, whereas MIKC genes and several 
M $\delta$ genes contained multiple introns. The similar situation existed in arabidopsis, rice, cucumber, and apple (Malus ×domestica) (Arora et al., 2007; Hu et al., 2012; Pařenicová et al., 2003; Tian et al., 2015). These results suggested that the structure of MADS-box genes was conservative relatively in these species.

Previous studies have shown that MADS-box genes of diverse subfamilies have different expression patterns in different tissues of arabidopsis, grape, apple, and cucumber. For example, AP3/PI subclass genes are specifically expressed in grape flowers, cucumber fruit, and apple stems, leaves, and flowers, whereas their expression was specific to and high in melon flowers. It is reported that the AP3/PI genes controlled the formation of petals and stamens during arabidopsis flower development, and might act as a switch between the activation of male and the repression of female development (Wuest et al., 2012). Thus, their expression suggested a role in melon flower development. AGL6 subclass genes have been found to be specifically expressed in cucumber fruit and grape flowers, whereas their expression was high in melon flowers and fruit. AGL17 genes are expressed at different levels in diverse tissues and are specifically expressed in grape fruit and cucumber roots; our results in melon were consistent with those in cucumber, with specific expression in roots. In melon, the expression levels of $\mathrm{M} \alpha$ and $\mathrm{M} \gamma$ subfamily genes were low, and some was even undetectable in roots, stems, flowers, and fruit at 0,15 , and 35 DAP. But a low transcript level of MADS37 and MADS38 was detected in fruit at 0 DAP, and MADS40 in flowers. Quantitative results showed that MADS40 was expressed specifically in flowers, and the relative expression levels are about 170 times than other tissues. We infer that genes of both of these subfamilies are pseudo genes, or are expressed only in specific tissues or at a specific stage. SEP-like genes are expressed in a range of species with fleshy fruits, including tomato (Solanum lycopersicum), peach, strawberry (Fragaria $\times$ ananassa), and so on. It was highly expressed during fruit ripening in tomato and strawberry, and suppression of the gene delayed normal fruit ripening (Seymour et al., 2011; Vrebalov et al., 2002). In this study, the expression of SEP-like gene CmMADS26 increased gradually with the mature of melon fruit. Hence, it is tempting to speculate that the gene CmMADS26 may play similar roles in melon. These data generated here will be useful for analysis of the biological functions of MADS-box family genes in melon growth and development.

In brief, 62 MADS-box genes in melon distributed across its 12 chromosomes, often located within the same small chromosomal region in clusters of two or more genes. Phylogenetic comparisons and expression analysis in this study will provide information for understanding the classification, cloning, and predicting biological functions of the family in melon.

\section{Literature Cited}

Adamczyk, B.J. and D.E. Fernandez. 2009. MIKC* MADS domain heterodimers are required for pollen maturation and tube growth in Arabidopsis. Plant Physiol. 149(4):1713-1723.

Alvarez-Buylla, E.R., S. Pelaz, S.J. Liljegren, S.E. Gold, C. Burgeff, G.S. Ditta, L.R. De Pouplana, L. Martínez-Castilla, and M.F. Yanofsky. 2000. An ancestral MADS-box gene duplication occurred before the divergence of plants and animals. Proc. Natl. Acad. Sci. USA 97(10):5328-5333.
Arora, R., P. Agarwal, S. Ray, A.K. Singh, V.P. Singh, A.K. Tyagi, and S. Kapoor. 2007. MADS-box gene family in rice: Genome-wide identification, organization and expression profiling during reproductive development and stress. BMC Genomics 8(33):1-21.

Bailey, T.L. and C. Elkan. 1994. Fitting a mixture model by expectation maximization to discover motifs in bipolymers. Proc. Intl. Conf. Intell. Syst. Mol. Biol. 2:28-36.

Becker, A., K.U. Winter, B. Meyer, H. Saedler, and G. Theissen. 2000. MADS-box gene diversity in seed plants 300 million years ago. Mol. Biol. Evol. 17(10):1425-1434.

Beijing Genomics Institute (BGI). 2009. Cucumber Genome Database. 3 June 2015. <http://cucumber.genomics.org.cn/page/cucumber/ genedetail.jsp?id=921\&dbKey=Cucumber $>$.

Causier, B., M. Kieffer, and B. Davies. 2002. MADS-box genes reach maturity. Science 296(5566):275-276.

Coen, E.S. and E.M. Meyerowitz. 1991. The war of the whorls: Genetic interactions controlling flower development. Nature 353 (6339):31-37.

Davies, B., M. Egea-Cortines, E. de Andrade Silva, H. Saedler, and H. Sommer. 1996. Multiple interactions amongst floral homeotic MADS box proteins. EMBO J. 15(16):4330-4343.

De Bodt, S., J. Raes, Y. Van de Peer, and G. Theissen. 2003. And then there were many: MADS goes genomic. Trends Plant Sci. 8(10):475-483.

Díaz-Riquelme, J., D. Lijavetzky, J.M. Martínez-Zapater, and M.J. Carmona. 2009. Genome-wide analysis of MIKC $^{\mathrm{C}}$-type MADS box genes in grapevine. Plant Physiol. 149(1):354-369.

Ditta, G., A. Pinyopich, P. Robles, S. Pelaz, and M.F. Yanofsky. 2004. The SEP4 gene of Arabidopsis thaliana functions in floral organ and meristem identity. Curr. Biol. 14(21):1935-1940.

Duan, W., X. Song, T. Liu, Z. Huang, J. Ren, X. Hou, and Y. Li. 2014. Genome-wide analysis of the MADS-box gene family in Brassica rapa (Chinese cabbage). Mol. Genet. Genomics 290(1):239-255.

Fang, S.C. and D.E. Fernandez. 2002. Effect of regulated overexpression of the MADS domain factor AGL15 on flower senescence and fruit maturation. Plant Physiol. 130(1):78-89.

Favaro, R., A. Pinyopich, R. Battaglia, M. Kooiker, L. Borghi, G. Ditta, M.F. Yanofsky, M.M. Kater, and L. Colombo. 2003. MADSbox protein complexes control carpel and ovule development in Arabidopsis. Plant Cell 15(11):2603-2611.

Finn, R.D., A. Bateman, J. Clements, P. Coggill, R.Y. Eberhardt, S.R. Eddy, A. Heger, K. Hetherington, L. Holm, J. Mistry, E.L. Sonnhammer, J. Tate, and M. Punta. 2014. Pfam: The protein families database. Nucl. Acids Res. 42:D222-D230.

Garcia-Mas, J., A. Benjak, W. Sanseverino, M. Bourgeois, G. Mir, V.M. González, E. Hénaff, F. Câmara, L. Cozzuto, and E. Lowy. 2012. The genome of melon (Cucumis melo L.). Proc. Natl. Acad. Sci. USA 109(29):11872-11877

Hall, T.A. 1999. BioEdit: A user-friendly biological sequence alignment editor and analysis program for Windows 95/98/NT. Nucl. Acids Symp. Ser. 41:95-98.

Henschel, K., R. Kofuji, M. Hasebe, H. Saedler, T. Münster, and G. Theissen. 2002. Two ancient classes of MIKC-type MADS-box genes are present in the moss Physcomitrella patens. Mol. Biol. Evol. 19(6):801-814.

Honma, T. and K. Goto. 2001. Complexes of MADS-box proteins are sufficient to convert leaves into floral organs. Nature 409 (6819):525-529.

Hu, B., J. Jin, A.Y. Guo, H. Zhang, J. Luo, and G. Gao. 2015. GSDS 2.0: An upgraded gene feature visualization server. Bioinformatics 31(8):1296-1297.

Hu, L., S. Liu, and D. Somers. 2012. Genome-wide analysis of the MADS-box gene family in cucumber. Genome 55(3):245-256.

Jaillon, O., J.M. Aury, B. Noel, A. Policriti, C. Clepet, A. Casagrande, N. Choisne, S. Aubourg, N. Vitulo, C. Jubin, A. Vezzi, F. Legeai, P. Hugueney, C. Dasilva, D. Horner, E. Mica, D. Jublot, J. Poulain, C. Bruyère, A. Billault, B. Segurens, M. Gouyvenoux, E. Ugarte, F. Cattonaro, V. Anthouard, V. Vico, C. Del Fabbro, M. Alaux, 
G. Di Gaspero, V. Dumas, N. Felice, S. Paillard, I. Juman, M. Moroldo, S. Scalabrin, A. Canaguier, I. Le Clainche, G. Malacrida, E. Durand, G. Pesole, V. Laucou, P. Chatelet, D. Merdinoglu, M. Delledonne, M. Pezzotti, A. Lecharny, C. Scarpelli, F. Artiguenave, M.E. Pè, G. Valle, M. Morgante, M. Caboche, A.F. Adam-Blondon, J. Weissenbach, F. Quétier, P. Wincker; French-Italian Public Consortium for Grapevine Genome Characterization. 2007. The grapevine genome sequence suggests ancestral hexaploidization in major angiosperm phyla. Nature 449(7161):463-467.

Kaufmann, K., R. Melzer, and G. Theissen. 2005. MIKC-type MADSdomain proteins: Structural modularity, protein interactions and network evolution in land plants. Gene 347(2):183-198.

Kramer, E.M., R.L. Dorit, and V.F. Irish. 1998. Molecular evolution of genes controlling petal and stamen development: Duplication and divergence within the APETALA3 and PISTILLATA MADS-box gene lineages. Genetics 149(2):765-783.

Lee, S., Y.M. Woo, S.I. Ryu, Y.D. Shin, W.T. Kim, K.Y. Park, I.J. Lee, and G. An. 2008. Further characterization of a rice AGL12 group MADS-box gene, OsMADS26. Plant Physiol. 147(1):156-168.

Leseberg, C.H., A. Li, H. Kang, M. Duvall, and L. Mao. 2006. Genome-wide analysis of the MADS-box gene family in Populus trichocarpa. Gene 378:84-94.

Letunic, I., T. Doerks, and P. Bork. 2015. SMART: Recent updates, new developments and status in 2015. Nucl. Acids Res. 43(D1): D257-D260.

Liljegren, S.J., G.S. Ditta, Y. Eshed, B. Savidge, J.L. Bowman, and M.F. Yanofsky. 2000. SHATTERPROOF MADS-box genes control seed dispersal in Arabidopsis. Nature 404(6779):766-770.

Liu, R.H. and J.L. Meng. 2003. MapDraw: A Microsoft Excel macro for drawing genetic linkage maps based on given genetic linkage data. Heraditas 25(3):317-321.

Ma, H. 2000. The ABCs of floral evolution. Cell 101(1):5-8.

Ma, H. 2005. Molecular genetic analyses of microsporogenesis and microgametogenesis in flowering plants. Annu. Rev. Plant Biol. 56:393-434.

Ma, H., M.F. Yanofsky, and E.M. Meyerowitz. 1991. AGL1-AGL6, an Arabidopsis gene family with similarity to floral homeotic and transcription factor genes. Genes Dev. 5(3):484-495.

Michaels, S.D., G. Ditta, C. Gustafson-Brown, S. Pelaz, M. Yanofsky, and R.M. Amasino. 2003. AGL24 acts as a promoter of flowering in Arabidopsis and is positively regulated by vernalization. Plant $\mathrm{J}$. 33(5):867-874.

Nesi, N., I. Debeaujon, C. Jond, A.J. Stewart, G.I. Jenkins, M. Caboche, and L. Lepiniec. 2002. The TRANSPARENT TESTA16 locus encodes the ARABIDOPSIS BSISTER MADS domain protein and is required for proper development and pigmentation of the seed coat. Plant Cell 14(10):2463-2479.

Norman, C., M. Runswick, R. Pollock, and R. Treisman. 1988. Isolation and properties of cDNA clones encoding SRF, a transcription factor that binds to the c-fos serum response element. Cell 55(6):989-1003.

Pařenicová, L., S.D. Folter, M. Kieffer, D.S. Horner, C. Favalli, J. Busscher, H.E. Cook, R.M. Ingram, M.M. Kater, and B. Davies. 2003. Molecular and phylogenetic analyses of the complete MADSbox transcription factor family in Arabidopsis new openings to the MADS world. Plant Cell 15(7):1538-1551.

Passmore, S., G.T. Maine, R. Elble, C. Christ, and B.K. Tye. 1988. Saccharomyces cerevisiae protein involved in plasmid maintenance is necessary for mating of MAT alpha cells. J. Mol. Biol. 204(3):593-606. Paterson, A.H., J.E. Bowers, R. Bruggmann, I. Dubchak, J. Grimwood, H. Gundlach, G. Haberer, U. Hellsten, T. Mitros, A. Poliakov, J. Schmutz, M. Spannagl, H. Tang, X. Wang, T. Wicker, A.K. Bharti, J. Chapman, F.A. Feltus, U. Gowik, I.V. Grigoriev, E. Lyons, C.A. Maher, M. Martis, A. Narechania, R.P. Otillar, B.W. Penning, A.A. Salamov, Y. Wang, L. Zhang, N.C. Carpita, M. Freeling, A.R. Gingle, C.T. Hash, B. Keller, P. Klein, S. Kresovich, M.C. McCann, R. Ming, D.G. Peterson, Mehboob-ur-Rahman, D. Ware, P. Westhoff, K.F. Mayer, J. Messing, and D.S. Rokhsar. 2009. The
Sorghum bicolor genome and the diversification of grasses. Nature 457(7229):551-556.

Pelaz, S., G.S. Ditta, E. Baumann, E. Wisman, and M.F. Yanofsky. 2000. B and C floral organ identity functions require SEPALLATA MADS-box genes. Nature 405(6783):200-203.

Pere, P. and G.M. Jordi. 2012. MELONOMICS. 5 May 2015. $<$ melonomics.net/files/Genome/Melon_genome_v3.5.1 $>$.

Pinyopich, A., G.S. Ditta, B. Savidge, S.J. Liljegren, E. Baumann, E. Wisman, and M.F. Yanofsky. 2003. Assessing the redundancy of MADSbox genes during carpel and ovule development. Nature 424(6944):85-88. Pnueli, L., M. Abu-Abeid, D. Zamir, W. Nacken, Z. Schwarz-Sommer, and E. Lifschitz. 1991. The MADS box gene family in tomato: Temporal expression during floral development, conserved secondary structures and homology with homeotic genes from Antirrhinum and Arabidopsis. Plant J. 1(2):255-266.

Rhee, S.Y., W. Beavis, T.Z. Berardini, G. Chen, D. Dixon, A. Doyle, M. Garcia-Hernandez, E. Huala, G. Lander, and M. Montoya. 2003. The Arabidopsis Information Resource (TAIR): A model organism database providing a centralized, curated gateway to Arabidopsis biology, research materials and community. Nucl. Acids Res. 31:224-228.

Riechmann, J.L., B.A. Krizek, and E.M. Meyerowitz. 1996. Dimerization specificity of Arabidopsis MADS domain homeotic proteins APETALA1, APETALA3, PISTILlATA, and AGAMOUS. Proc. Natl. Acad. Sci. USA 93(10):4793-4798.

Schmutz, J., S.B. Cannon, J. Schlueter, J. Ma, T. Mitros, W. Nelson, D.L. Hyten, Q. Song, J.J. Thelen, J. Cheng, D. Xu, U. Hellsten, G.D. May, Y. Yu, T. Sakurai, T. Umezawa, M.K. Bhattacharyya, D. Sandhu, B. Valliyodan, E. Lindquist, M. Peto, D. Grant, S. Shu, D. Goodstein, K. Barry, M. Futrell-Griggs, B. Abernathy, J. Du, Z. Tian, L. Zhu, N. Gill, T. Joshi, M. Libault, A. Sethuraman, X.C. Zhang, K. Shinozaki, H.T. Nguyen, R.A. Wing, P. Cregan, J. Specht, J. Grimwood, D. Rokhsar, G. Stacey, R.C. Shoemaker, and S.A. Jackson. 2010. Genome sequence of the palaeopolyploid soybean. Nature 463(7278):178-183.

Schnable, P.S., D. Ware, R.S. Fulton, J.C. Stein, F. Wei, S. Pasternak, C. Liang, J. Zhang, L. Fulton, and T.A. Graves. 2009. The B73 maize genome: Complexity, diversity, and dynamics. Science 326 (5956):1112-1115.

Schultz, J., F. Milpetz, P. Bork, and C.P. Ponting. 1998. SMART, a simple modular architecture research tool: Identification of signaling domains. Proc. Natl. Acad. Sci. USA 95(11):5857-5864.

Seymour, G.B., C.D. Ryder, V. Cevik, J.P. Hammond, A. Popovich, G.J. King, J. Vrebalov, J.J. Giovannoni, and K. Manning. 2011. A SEPALLATA gene is involved in the development and ripening of strawberry (Fragaria $\times$ ananassa Duch.) fruit, a non-climacteric tissue. J. Expt. Bot. 62(3):1179-1188.

Shu, Y., D. Yu, D. Wang, D. Guo, and C. Guo. 2013. Genome-wide survey and expression analysis of the MADS-box gene family in soybean. Mol. Biol. Rpt. 40(6):3901-3911.

Sommer, H., J.P. Beltran, P. Huijser, H. Pape, W. Lönnig, H. Saedler, and Z. Schwarz-Sommer. 1990. Deficiens, a homeotic gene involved in the control of flower morphogenesis in Antirrhinum majus: The protein shows homology to transcription factors. EMBO J. 9(3):605-613.

Tamura, K., J. Dudley, M. Nei, and S. Kumar. 2007. MEGA4: Molecular evolutionary genetics analysis (MEGA) software version 4.0. Mol. Biol. Evol. 24(8):1596-1599.

Tapia-López, R., B. García-Ponce, J.G. Dubrovsky, A. Garay-Arroyo, R.V. Pérez-Ruíz, S.H. Kim, F. Acevedo, S. Pelaz, and E.R. AlvarezBuylla. 2008. An AGAMOUS-related MADS-box gene, XAL1 (AGL12), regulates root meristem cell proliferation and flowering transition in Arabidopsis. Plant Physiol. 146(3):1182-1192.

Theissen, G., A. Becker, A.D. Rosa, A. Kanno, J.T. Kim, T. Münster, K.U. Winter, and H. Saedler. 2000. A short history of MADS-box genes in plants. Plant Mol. Evol. 42:115-149.

Tian, Y., Q. Dong, Z. Ji, F. Chi, P. Cong, and Z. Zhou. 2015. Genomewide identification and analysis of the MADS-box gene family in apple. Gene 555(2):277-290. 
Vrebalov, J., D. Ruezinsky, V. Padmanabhan, R. White, D. Medrano, R. Drake, W. Schuch, and J. Giovannoni. 2002. A MADS-box gene necessary for fruit ripening at the tomato ripening-inhibitor (rin) locus. Science 296(5566):343-346.

Wells, C.E., E. Vendramin, S.J. Tarodo, I. Verde, and D.G. Bielenberg. 2015. A genome-wide analysis of MADS-box genes in peach [Prunus persica (L.) Batsch]. BMC Plant Biol. 15(1):1-15.
Wuest, S.E., D.S. O’Maoileidigh, L. Rae, K. Kwasniewska, A. Raganelli, K. Hanczaryk, A.J. Lohan, B. Loftus, E. Graciet, and F. Wellmer. 2012. Molecular basis for the specification of floral organs by APETALA3 and PISTILLATA. Proc. Natl. Acad. Sci. USA 109(33):13452-13457. Yanofsky, M.F., H. Ma, J.L. Bowman, G.N. Drews, K.A. Feldmann, and E.M. Meyerowitz. 1990. The protein encoded by the Arabidopsis homeotic gene agamous resembles transcription factors. Nature 346(6279):35-39. 